\title{
Investment Projects in Oil and Gas Industry in Uzbekistan
}

\author{
Ph.D. Candidate Dinora Ishmanova (Tashkent State University of Economics, Uzbekistan)
}

\begin{abstract}
In recent years, the oil and gas industry of Uzbekistan has been developing very fast, and oil and gas production has grown significantly. Uzbekistan achieved oil independence. Natural gas fields in the Republic are being exported to foreign countries as well as satisfying the needs of all types of industrial enterprises and population. Growth of oil and gas extraction is achieved by opening up of new oil and gas constructions and fields, increasing the efficiency of mining operations, and applying new methods of increasing the level of resource utilization. Determining the ultimate goal of socio-economic transformations in our country is the starting point of the current reform strategy. At the same time, the focus is on ensuring the dynamic development of the fuel and energy complex, increasing oil and gas extraction and processing, and gaining energy independence of the republic. LUKOIL is one of the world's largest vertically -Integrated companies engaged in the extraction and processing of oil and gas, manufacturing of petroleum products and petrochemicals. The main areas of its activity, the Company holds a leading position in the Russian and global markets.
\end{abstract}

\section{Introduction}

The Republic of Uzbekistan is one of key regions of activity in which LUKOIL realizes the megaprojects. The general saved-up volume of investment of LUKOIL into economy of Uzbekistan has exceeded 3,2 billion dollars, and for the entire period of implementation of the existing projects till 2041 is planned investments of more than 8 billion dollars that does the Company by the largest investor in the country. In the medium term 2018 LUKOIL in Uzbekistan plans to reach level of production of 18 billion cubic meters of gas a year and to extract about 330 billion cubic meters of gas and about 10 billion tons of oil and gas condensate for period of validity of the Production Sharing Agreement. Revenues of the state for all term of implementation of projects of LUKOIL in Uzbekistan will make more than 40 billion dollars. An operator of projects in Uzbekistan is LLC LUKOIL Uzbekistan Opereyting of the Company (Subsidiary "LUKOIL Overseas Uzbekistan Ltd.") with head office in Tashkent. In the Operator $85 \%$ of personnel work. The strategic partner in projects - Uzbekneftegaz Joint stock company. The production sharing agreement concerning the site of Kandym group of fields, sites Hauzak and Shada and also the Kungradsky site ("Kandym-Hauzak-Shady-Kungrad" project) period of validity of 35 years has come into force of 2004, then also field works have begun. Drilling on the first starting site of the project gas field of Hauzak-Shada in the Bukhara region has begun summer of 2006, start of trade in operation has taken place in November, 2007. Exactly a year later design level gas production has been reached here. At the end of 2011 gas production on the western part of the site of Shada is begun. Volume production in 2013 was 3,74 billion cubic meters of gas and 13,2 thousand tons of gas condensate. Additional exploration of the field continues, in particular, in a northern part of the site of Shada which is supposed will bring into operation in 2015 with essential increase in production.

The consortium of investors has started drilling of the search Meros-1Ex well on structure of Meros on the Aral Sea revealed by results of seismoprospecting works 3D. Drilling of the Meros-1Ex well is carried out by XIBU Drilling Engineering Company contract organization (People's Republic of China). Design depth of the well is $3280 \mathrm{~m}$, the target horizon - the Jurassic deposits. For ensuring journey to the well construction of the temporary highway with a total length of $16 \mathrm{~km}$ is complete. Works are conducted according to the resolution of the President of the Republic of Uzbekistan "About additional measures for further implementation of the Production sharing agreement concerning the Uzbek part of the Aral Sea" No. PP-2059 from 10/30/2013. The operating company JV LLC Aral Sea Si Opereyting Company has begun work on the Uzbek part of the Aral Sea within the Production sharing agreement (Production Sharing Agreement) signed in August, 2006. The project realizes consortium of investors as a part of the Russian company "LUKOIL", Uzbekneftegaz Joint stock company and China National Petroleum Corporation. Within the prospecting period of the Production Sharing Agreement on contract area nearly three thousand running kilometers of $2 \mathrm{D}$ and 780 square kilometers of $3 \mathrm{D}$ seismic researches are at the moment executed, five explorative wells are drilled. In the modern world the mankind in many respects depends on oil. Oil as a product, certainly, is connected with the national strategy, development of economy, world politics and the power. Oil gives wealth to the states, does them by the center of gravity of internal and external investments, having provided them high income, allocates with the political power. The end of 40th and 50th were marked by the sharp growth of number of researches in the field of development of oil fields, development of the new directions in this area. The solution of the problem of development of oil fields at the mixed modes has been considerably advanced — water-pressure and the dissolved gas. Methods of determination of parameters of layers with use of hydrodynamic well surveys have begun to develop intensively. Methodical bases of calculation of development of oil fields with application of probabilistic and statistical models have been created. Also, methods of direct accounting of heterogeneity at filtration in oil layers developed. Holding actions for regulation of development of oil fields is connected with additional, in comparison with design, current and capital expenditure. 
If the given costs of regulation of mining are in limits of $10-20 \%$ of the total given expenses and if these expenses don't increase eventually, and process of development satisfies to a problem of optimum development oil production in the country in general, then it is approximately possible to consider that further development should be continued on the accepted design document. In opposite cases it is asked about preparation of the new design decision on mining.

The events of the expiring year connected with global financial and economic crisis force experts to make in the most various spheres the assumptions concerning as far as on time world stagnation will drag on and in what ways it will be possible to get out of him in the shortest possible time. The defining factor in all these forecasts is the condition of world power and those oil and gas combinations which next year will already determine rates of economic development practically of all countries of the world. Kandym gas-processing a complex in the Bukhara region of Uzbekistan - one of the most large-scale investment projects of LUKOIL. The sum of investments nearly 3,5 billion dollars. On the Kandym field of 77 wells, system of collecting natural gas. Complex power eight billion cubic meters a year. At a construction stage about 10 thousand people have been involved in works. After start of an object more than two thousand new jobs are created. After Uzbekistan gained its independence, it entered the 21 st century as the world's top ten economy leaders in over 90 world-class natural gas producers

\begin{tabular}{|l|l|l|l|}
\hline № & Name of countries & $\begin{array}{l}\text { Annual natural gas } \\
\text { production billion } \\
\text { cubic m. }\end{array}$ & $\begin{array}{l}\text { His share in the } \\
\text { world market as } \\
\text { a percentage }\end{array}$ \\
\hline 1 & Russian Federation & 647 & 18 \\
\hline 2 & USA & 619 & 17 \\
\hline 3 & Canada & 158 & 4 \\
\hline 4 & Iran & 152 & 4 \\
\hline 5 & Norway & 110 & 3 \\
\hline 6 & China & 98 & 2,7 \\
\hline 7 & Netherlands & 89 & 2,4 \\
\hline 8 & Indonesia & 82 & 2,2 \\
\hline 9 & Saudi Arabia & 77 & 2,1 \\
\hline 10 & Algeria & 68 & 1,9 \\
\hline 11 & Turkmenistan & 66,2 & 1,8 \\
\hline 12 & Uzbekistan & 65 & 1,8 \\
\hline 13 & Egypt & 63 & 1,7 \\
\hline 14 & Great Britain & 60 & 1,6 \\
\hline 15 & Malaysia & 59 & 1,6 \\
\hline 16 & India & 53 & 1,5 \\
\hline 17 & United Arab Emirates & 52 & 1,5 \\
\hline 18 & Mexico & 50 & 1,4 \\
\hline 19 & Australia & 45 & 1,2 \\
\hline 20 & Azerbaijan & 41 & 1,1 \\
\hline
\end{tabular}

Table 1. The World's 20 Largest Natural Gas Producers Source: Uzbekneftegas Join-Stock Company (1)

LUKOIL works in Uzbekistan 15 years. Cumulative investments into all projects of LUKOIL in the country have exceeded seven billion dollars. On April 19 the opening ceremony of Kandym gas processing plant in the Karakul district was held. The Kandym GPP is the next bright embodiment of cooperation of Uzbekistan and Russia. The head of our state has noted that the work which is carried out within the Strategy of actions serves consecutive development of the leading industries. Active attraction of direct foreign investments in fuel and energy branch and Kandymsky gas processing plant are the next bright embodiment of cooperation of Uzbekistan and Russia It is noted that its capacities are calculated on processing in a year of 8,1 billion cubic meters of gas. Having left at full capacity, properly further, the complex will produce a year 212 thousand tons of pure sulfur, 134 thousand tons of the stabilized gas condensate, the purified natural gas will be sent for export.

In summary:

- Most of the investment in the domestic industry accounts for the fuel and energy complex, which is explained by the technical and technological re-equipment of the complex, the implementation of investment projects of strategic importance;

- The Uzbek oil and gas industry has a complex of raw material extraction and processing; 6 joint-stock companies and other affiliates of the Uzbekneftegaz are included in the system, which is comprised of more than 190 enterprises;

- The prerequisite for increasing investment attractiveness of oil and gas companies of the country is the application of effective dividend policy. 


\section{References}

- Ishmanova,2014 "Regulation of oil and gas system management in the Republic of Uzbekistan" Master's degree dissertation, p. 78

- Sh. Mirziyoyev 2018 Opening Ceremony of Kandym Gas Processing Complex, Established by Uzbekneftegaz Joint-Stock Company and Russian LUKOIL Company. Bukhara

- Uzbekneftegaz, 2018 statistics, www.ung,uz

Citations in the text

(1) Sh. Mirziyoyev 2018 Opening Ceremony of Kandym Gas Processing Complex, Established by Uzbekneftegaz Joint-Stock Company and Russian LUKOIL Company. Bukhara 